\title{
PENGARUH ARAH PENGEROLAN DAN SHEAR CUTTING TERHADAP KARAKTER PADUAN AIMg2 SEBAGAI MATERIAL CLADDING BAHAN BAKAR REAKTOR RISET
}

\author{
Sungkono, Sri Ismarwanti \\ Pusat Teknologi Bahan Bakar Nuklir - BATAN \\ Kawasan PUSPIPTEK Serpong Gd.20 Tangerang Selatan, Banten 15314 \\ e-mail: sungkhana@gmail.com
}

(Naskah diterima: 3-10-2020, Naskah direvisi: 11-10-2020, Naskah disetujui: 27-10-2020)

\begin{abstract}
ABSTRAK
PENGARUH ARAH PENGEROLAN DAN SHEAR CUTTING TERHADAP KARAKTER PADUAN AIMg2 SEBAGAI MATERIAL CLADDING BAHAN BAKAR REAKTOR RISET. Proses pengerolan paduan AIMg2 dilakukan secara bertahap hingga diperoleh ketebalan tertentu dengan syarat perilaku mekanik akhir sesuai spesifikasi cladding bahan bakar reaktor riset. Pada pengujian tarik elemen bakar pasca iradiasi digunakan spesimen mini untuk meminimalkan limbah radioaktif. Tujuan penelitian adalah mendapatkan pengaruh arah pengerolan dan shear cutting terhadap karakter paduan AIMg2. Metode yang digunakan adalah pengujian tarik, metalografi dan kekerasan pada sampel pasca pengerolan dan spesimen mini paduan AIMg2. Hasil penelitian menunjukkan bahwa paduan AIMg2 searah pengerolan mempunyai kekuatan tarik dan kekerasan lebih rendah dan lebih ulet dibandingkan arah melintang pengerolan. Struktur paduan AIMg2 pasca pengerolan panas terdiri atas fasa $\alpha(\mathrm{Al})$ dan presipitat yang terdistribusi di sepanjang butir batang pipih searah pengerolan sampel. Shear cutting mempengaruhi lebar dan kekerasan daerah deformasi pada permukaan bekas potong spesimen mini.
\end{abstract}

Kata kunci: arah pengerolan, shear cutting, paduan AlMg2, kekuatan tarik, kekerasan, mikrostruktur. 


\begin{abstract}
THE INFLUENCE OF ROLLING DIRECTION AND SHEAR CUTTING ON THE CHARACTERISTICS OF AIMg2 AS FUEL CLADDING MATERIAL FOR RESEARCH REACTOR

FUEL. Gradual rolling process of AIMg2 alloy has been carried out to obtain a certain thickness with final mechanical behavior suitable for fuel cladding of research reactor. The post-irradiation testing of fuel element used mini specimens to minimize radioactive waste. The purpose of this study was to study the influence of rolling direction and shear cutting on AIMg2 alloy characteristics. The tests performed include tensile, metalographic and hardness tests after rolling. The results show that AIMg2 alloy rolled by same direction has lower tensile strength and hardness and is more ductile than that rolled by transverse direction. The structure of AIMg2 alloy after hot rolling consists of $\alpha(A l)$ phase with precipitates distributed along the elongated grains in the rolling direction. Shear cutting affects the width and hardness of the deformation area on the cut surface of the specimens.
\end{abstract}

Keywords: rolling direction, shear cutting, AIMg2 alloy, tensile strength, hardness, microstructure. 


\section{PENDAHULUAN}

Elemen bakar tipe pelat (PEB) $\mathrm{U}_{3} \mathrm{Si}_{2}$ dengan densitas $2,96 \mathrm{gU} / \mathrm{cm}^{3}$ sampai saat ini digunakan sebagai bahan bakar reaktor riset G.A. Siwabessy di Serpong. Bahan bakar tersebut menggunakan bahan struktur dari paduan Aluminium. Dalam hal ini, material cladding dibuat dari paduan AA 5052 (AlMg2). Cladding merupakan bagian dari elemen bakar yang memberikan kekuatan struktur dan sebagai wadah untuk melindungi lepasan produk fisi dari bahan bakar ke air pendingin $[1,2]$.

Paduan AIMg2 dipilih sebagai material cladding bahan bakar reaktor riset karena mempunyai tampang lintang serapan neutron termal rendah $(=0,23$ barn $)$, ketahanan oksidasi dan kekuatan mekanik cukup baik pada temperatur sekitar $100^{\circ} \mathrm{C}$, konduktivitas termal tinggi $(=137 \mathrm{~W} / \mathrm{m} . \mathrm{K})$, dan ketahanan korosi tinggi pada temperatur operasi, mudah difabrikasi, mampu las baik, murah dan mudah diperoleh di pasaran bila dibandingkan paduan Aluminium lainnya $[1,3]$. Selain itu, paduan AIMg2 mempunyai densitas $2,68 \mathrm{~g} / \mathrm{cm}^{3}$, titik lebur $650{ }^{\circ} \mathrm{C}$, serta perilaku mekanik pada temperatur kamar, yaitu kekuatan tarik $170 \mathrm{MPa}$, kekuatan luluh $58 \mathrm{MPa}$, perpanjangan 18-21\%, dan modulus elastisitas Young $71 \mathrm{GPa}[1,4]$.

Di dalam reaktor nuklir, cladding bahan bakar mengalami beban akibat swelling bahan bakar, produk fisi yang terbentuk dan panas hasil reaksi fisi. Sehubungan hal tersebut, maka material cladding harus mempunyai kekuatan dan keuletan tinggi agar mampu menahan tegangan internal yang terjadi [5]. Ketebalan cladding AIMg2 yang dibutuhkan PEB $\mathrm{U}_{3} \mathrm{Si}_{2} / \mathrm{Al}$ dengan densitas $2,96 \mathrm{gU} / \mathrm{cm}^{3}$ adalah $0,38 \mathrm{~mm}$, sehingga dimensi PEB $\mathrm{U}_{3} \mathrm{Si}_{2} / \mathrm{Al}$ adalah panjang $70 \mathrm{~cm}$, lebar $7 \mathrm{~cm}$ dan ketebalan 1,34 mm [6]. Ketebalan cladding tersebut ditentukan berdasarkan pada beberapa persyaratan, antara lain: temperatur cladding maksimum $145^{\circ} \mathrm{C}$, temperatur meat maksimum $207{ }^{\circ} \mathrm{C}$, perbandingan antara kecepatan pendingin terhadap kecepatan kritisnya antara 0,63 hingga 0,85 dengan harga ketidakstabilan aliran lebih besar dari 2,67 [3, 6].

Salah satu tahapan proses fabrikasi bahan bakar nuklir adalah penyiapan material cladding sesuai dengan spesifikasi yang dipersyaratkan. Bahan awal yang dipakai adalah paduan AIMg2 dengan ketebalan $6 \mathrm{~mm}$. Bahan tersebut direduksi ketebalannya dengan cara pengerolan dingin secara bertahap hingga ketebalan $3,10 \mathrm{~mm}$. Selanjutnya, AIMg2 dipanaskan pada $400^{\circ} \mathrm{C}$ dan ditahan 60 menit kemudian dirol secara bertahap dan terakhir dirol dingin hingga diperoleh ketebalan 1,15 mm [6]. Pengerolan panas digunakan untuk mereduksi ketebalan bahan dengan deformasi besar tanpa retak, sedangkan pengerolan dingin dengan reduksi ketebalan kecil untuk meratakan permukaan dan meningkatkan kekuatan mekanik bahan. Produk material cladding pasca pengerolan harus mempunyai perilaku mekanik sesuai spesifikasi yang dipersyaratkan bahan bakar reaktor riset $[7,8]$.

Setelah proses fabrikasi selesai akan dihasilkan PEB yang kualitasnya dapat diketahui dari data hasil uji pra dan pasca iradiasi, meliputi uji tak merusak dan uji merusak. Salah satu uji merusak elemen bakar nuklir adalah uji tarik. Dalam pengujian tarik PEB pasca iradiasi yang dilakukan di hot cell 111 perlu dipertimbangkan beberapa hal, seperti kemudahan dalam penanganan dan limbah yang dihasilkan minimal karena berpotensi meningkatkan paparan radiasi dan kontaminasi di dalam hot cell. Salah satu solusi yang digunakan dalam mengatasi permasalahan tersebut adalah pemakaian spesimen mini untuk menentukan perilaku tarik material cladding PEB[9]. Permasalahan yang timbul dalam pembuatan spesimen mini adalah deformasi pada permukaan bekas potong material dengan mesin punching. Efek shear cutting tersebut dapat dihilangkan dengan cara pengampelasan permukaan 
bekas potong atau pemotongan pada daerah deformasi dari spesimen mini.

Prochaska et al. dalam penelitiannya yang menggunakan spesimen mini mendapatkan bahwa kekuatan tariknya sebanding dengan kekuatan tarik spesimen standar, sedangkan regangannya lebih sensitif dibandingkan dengan regangan spesimen standar karena berkaitan dengan kekasaran permukaan dan mikrostruktur spesimen mini [9]. Bo Wang et al., telah melakukan penelitian terhadap paduan Al 5052 as cast yang dihomogenisasi pada $470{ }^{\circ} \mathrm{C}$ selama 15 jam dengan pendinginan sampel di udara. Sampel tersebut kemudian dirol dingin dengan reduksi ketebalan $15-87 \%$. Bo Wang mendapatkan bahwa meningkatnya reduksi ketebalan yang diterapkan pada paduan AA 5052 menyebabkan butir-butir ekuiaksial terelongasi di sepanjang arah pengerolan. Butir-butir tersebut terakumulasi sehingga meningkatkan efek pengerasan regangan yang memberikan dampak pada peningkatan kekuatan dan penurunan plastisitas paduan AA 5052 [7]. Menurut Rabenberg, perilaku tarik spesimen mini paduan aluminium teriradiasi dipengaruhi oleh beberapa faktor, antara lain kekasaran permukaan, ketebalan spesimen, dan kerusakan akibat radiasi [10].

Berdasarkan uraian tersebut di atas diketahui bahwa para peneliti sebelumnya hanya melakukan penelitian berkaitan dengan pengaruh kekasaran permukaan, ketebalan dan reduksi ketebalan terhadap perilaku tarik spesimen mini paduan $A A$ 5052. Sehubungan hal tersebut, maka dalam penelitian ini akan dilakukan karakterisasi paduan AlMg2 dengan ketebalan 1,40 mm dan $3,15 \mathrm{~mm}$ pasca pengerolan serta spesimen mini dengan ketebalan $1,40 \mathrm{~mm}$. Penelitian ini mempunyai tujuan untuk mendapatkan pengaruh arah pengerolan terhadap karakter paduan AIMg2 yaitu mikrostruktur, kekerasan, dan kekuatan tarikya, sedangkan spesimen mini untuk mengetahui daerah deformasi dan kekerasannya akibat shear cutting. Hipotesa penelitian yang diajukan adalah arah pengerolan dapat mempengaruhi bentuk dan ukuran butir dalam mikrostruktur dan shear cutting dapat menyebabkan terjadinya deformasi sehingga diduga dapat berpengaruh terhadap karakter mekanik dan mikrostruktur paduan AIMg2.

\section{METODOLOGI}

Bahan yang digunakan dalam penelitian ini adalah pelat AA 5052 (AIMg2) yang telah mengalami proses pengerolan panas dan dingin dengan ketebalan 1,40 mm dan $3,15 \mathrm{~mm}$. Selain itu juga digunakan bahan preparasi metalografi, seperti resin acryfic dan pengeras, kertas ampelas, kain poles, pasta intan, larutan etsa, dan alkohol untuk degreasing sampel metalografi.

Peralatan yang digunakan dalam penelitian ini adalah mesin punching, mesin accutom, mesin gerinda dan poles untuk preparasi dan mikroskop optik untuk pengamatan struktur mikro sampel metalografi. Spark spectrometer digunakan untuk pengujian komposisi kimia paduan AlMg2. Selain itu, mesin uji tarik digunakan untuk pengujian tarik dan microhardness Vickers tester untuk pengujian kekerasan sampel paduan AMg2.

Cara kerja yang dilakukan dalam penelitian ini adalah pembuatan sampel tarik dan spesimen mini, pengujian komposisi kimia, tarik dan kekerasan serta pengamatan mikrostruktur sampel tarik dan spesimen mini. Kedua tipe sampel tersebut dibuat searah dan melintang terhadap arah pengerolan material AIMg2. Selanjutnya, sampel dipilah untuk pengujian komposisi kimia, tarik, mikrostruktur, dan kekerasan. Sampel AlMg2 diuji komposisi kimianya dengan menggunakan spark spectrometer, sedangkan pengujian tariknya menggunakan mesin uji tarik kapasitas $5 \mathrm{kN}$.

Proses metalografi terhadap sampel pasca uji tarik dan sampel mini dilakukan dengan beberapa tahapan yaitu proses pemotongan untuk mendapatkan sampel metalografi, pembingkaian, penggerindaan, 
pemolesan, dan pengetsaan. Penggerindaan sampel menggunakan mesin gerinda dengan kertas ampelas grit 320 sampai dengan 2.000 mesh, dengan tujuan mendapatkan sampel yang datar, rata, dan bebas goresan. Pemolesan sampel menggunakan mesin poles dengan bahan poles pasta intan grit $0,1 \mu \mathrm{m}$, hingga diperoleh sampel yang datar, rata, licin, bebas goresan, dan mengkilap. Langkah berikutnya, sampel dietsa menggunakan metoda celup dengan Poulton Reagant[6]. Sampel pasca uji tarik di daerah patahan dan base metal serta daerah deformasi spesimen mini diamati struktur mikronya dengan mikroskop optik, sedangkan kekerasan mikro sampel ditentukan dengan microhardness Vickers tester menggunakan beban $100 \mathrm{gf}$.

\section{HASIL DAN PEMBAHASAN}

\section{Komposisi Kimia}

Komposisi kimia sampel diuji menggunakan spark spectrometer dengan tujuan untuk meyakinkan bahwa material tersebut adalah benar dan sesuai material yang dipersyaratkan sebagai material cladding bahan bakar nuklir untuk reaktor riset. Data hasil pengujian komposisi kimia paduan aluminium ditunjukkan pada Tabel 1 .

Tabel 1. Komposisi kimia paduan Aluminium.

\begin{tabular}{lcc}
\hline \multirow{2}{*}{ Unsur } & \multicolumn{2}{c}{ Komposisi, (wt.\%) } \\
\cline { 2 - 3 } & Sampel uji & $\begin{array}{c}\text { ASTM } \\
\text { B-209M-14 }\end{array}$ \\
\hline Aluminium (Al) & 96,7565 & Balance \\
Magnesium (Mg) & 2,7300 & $2,2-2,8$ \\
Khrom (Cr) & 0,1839 & $0,15-0,35$ \\
Besi (Fe) & 0,1230 & 0,40 max \\
Silikon (Si) & 0,1090 & 0,25 max \\
Mangan (Mn) & 0,0660 & 0,10 max \\
Zinc (Zn) & 0,0150 & 0,10 max \\
Tembaga (Cu) & 0,0053 & 0,10 max \\
Timah putih (Sn) & 0,0043 & - \\
Nikel (Ni) & 0,0030 & - \\
Timbal (Pb) & 0,0010 & - \\
Talium (Ta) & 0,0010 & - \\
Berilium (Be) & 0,0010 & - \\
Kalsium (Ca) & 0,0010 & - \\
\hline
\end{tabular}

Pada Tabel 1 diketahui komposisi utama paduan aluminium adalah Al (96,7565\%), Mg (2,73\%), Cr (0,1839\%), Fe $(0,123 \%)$, Si $(0,109 \%)$, Mn $(0,066 \%)$, Zn $(0,015 \%)$, dan $\mathrm{Cu}(0,0053 \%)$, sedangkan $\mathrm{Sn}, \mathrm{Ni}, \mathrm{Pb}, \mathrm{Ta}, \mathrm{Be}$ dan $\mathrm{Ca}$ merupakan unsur pengotor karena kandungannya sangat rendah $<0,005$ wt.\%. Dari komposisi unsur sampel paduan aluminium diketahui berada dalam rentang komposisi paduan AIMg2, yaitu $\mathrm{Mg}$ (2,2-2,8\%), Cr (0,15-0,35\%), $\mathrm{Fe}(0,40 \%$ max $)$, Si $(0,25 \%$ max $), \mathrm{Mn}(0,10 \%$ max.), Zn (0,10\% max), Cu (0,10\% max), dan Al setimbang[11][12]. Dengan demikian, sampel merupakan paduan AlMg2 yang digunakan sebagai material cladding bahan bakar uranium silisida.

\section{Perilaku tarik}

Perilaku tarik pelat paduan AIMg2 dapat diketahui dengan cara pengujian sampel tarik dengan dimensi seperti ditunjukkan pada Tabel 2. Pengujian tarik sampel AIMg2 menggunakan mesin uji tarik kapasitas $5 \mathrm{kN}$. Pada Tabel 3 diketahui bahwa untuk sampel arah melintang pengerolan yang mempunyai ketebalan dan lebar yang sama dengan gauge length lebih besar (sampel B) menunjukkan bahwa kekuatan tarik (UTS $=190,16 \mathrm{MPa}$ ), kekuatan luluh $\left(\sigma_{y}=117,28 \mathrm{MPa}\right)$, kekuatan patah $\left(\sigma_{f}=172,84 \mathrm{MPa}\right)$ dan regangan $(e=8,77 \%)$ lebih tinggi dibandingkan sampel dengan gauge length lebih kecil, yaitu sampel A yang mempunyai UTS $=165,70 \mathrm{MPa}, \sigma_{\mathrm{y}}=98,01$ $\mathrm{MPa}, \sigma_{\mathrm{f}}=146,50 \mathrm{MPa}$ dan $e=6.67 \%$. Hal ini disebabkan gauge length menentukan besarnya regangan $\left(=\Delta \mathrm{L} / \mathrm{L}_{0}\right)$ dan nisbah kerampingan $\left(=\mathrm{L}_{0} / \sqrt{ } \mathrm{A}_{0}\right)$ suatu material. Gauge length semakin besar maka regangan rekayasa semakin kecil, hal ini berarti kekuatan tarik rekayasa $(\sigma)$ material AIMg2 semakin besar sesuai dengan persamaan: $\sigma=E / e$, dengan $E$ adalah modulus elastisitas dan e adalah regangan rekayasa paduan AlMg2. 
Tabel 2. Dimensi sampel uji tarik paduan AlMg2.

\begin{tabular}{ccccccc}
\hline \multirow{2}{*}{ No } & \multicolumn{1}{c}{ Sampel } & $\begin{array}{c}\text { Panjang } \\
(\mathrm{l}), \mathrm{mm}\end{array}$ & $\begin{array}{c}\text { Lebar } \\
(\mathrm{w}), \mathrm{mm}\end{array}$ & $\begin{array}{c}\text { Ketebalan } \\
(\mathrm{t}), \mathrm{mm}\end{array}$ & $\begin{array}{c}\text { Luas Penampang } \\
(\mathrm{A}), \mathrm{mm}^{2}\end{array}$ \\
\cline { 2 - 3 } & Kode & Arah & 100,00 & 6,00 & 1,35 & 8,10 \\
\hline 1 & A & Melintang pengerolan & 150,00 & 6,00 & 1,35 & 8,10 \\
2 & B & Melintang pengerolan & 1,00 & 8,40 \\
3 & C & Searah pengerolan & 25,00 & 6,00 & 1,40 & 18.90 \\
4 & D & Melintang pengerolan & 25,00 & 6,00 & 3,15 & \\
\hline
\end{tabular}

Tabel 3. Data perilaku tarik paduan AIMg2.

\begin{tabular}{cccccc}
\hline \multirow{2}{*}{ No } & \multirow{2}{*}{ Sampel } & \multicolumn{3}{c}{ Kekuatan rerata, MPa } & \multirow{2}{*}{ Regangan (e), \% } \\
\cline { 2 - 5 } & A & UTS & $\sigma_{y}$ & $\sigma_{f}$ & 6,67 \\
\hline 1 & 165,70 & 98,01 & 146,50 & 8,77 \\
2 & $\mathrm{~B}$ & 190,16 & 117,28 & 172,84 & 27,55 \\
3 & $\mathrm{C}$ & 159,24 & 72,42 & 125,00 & 14,27 \\
4 & $\mathrm{D}$ & 217,59 & 191,88 & 167,55 & \\
\hline
\end{tabular}

Sementara itu, sampel arah melintang pengerolan (sampel D) yang mempunyai lebar sama dengan gauge length lebih kecil dan ketebalan lebih besar menunjukkan bahwa kekuatan tarik, kekuatan luluh, kekuatan patah dan regangannya lebih tinggi dibandingkan sampel A. Hal ini disebabkan luas penampang sampel memiliki efek yang signifikan terhadap perpanjangan, sehingga sampel D yang mempunyai nisbah kerampingan lebih kecil maka perpanjangan atau regangannya lebih besar dibandingkan sampel A. Oleh karena besarnya kekuatan tarik rekayasa berbanding terbalik dengan regangan rekayasa maka sampel $D$ mempunyai perilaku tarik lebih tinggi dibandingkan sampel A. Dari Tabel 3, sampel searah pengerolan (sampel $C$ ) dengan luas penampang sama dengan sampel arah melintang pengerolan menunjukkan perilaku tarik yang lebih ulet dibandingkan sampel $A$ dan B. Berdasarkan perilaku tariknya terlihat bahwa arah pengerolan mempunyai efek lebih dominan dibandingkan gauge length dari sampel.

Sampel paduan AIMg2 pasca pengerolan panas mempunyai struktur butir berbentuk batang pipih searah bidang pengerolan. Apabila mendapat tegangan tarik yang sama, maka tegangan yang diterapkan pada struktur butir searah pengerolan akan sejajar dengan bidang slip sehingga dislokasi dapat bergerak dengan mudah. Sebaliknya, tegangan tarik yang diterapkan pada struktur butir arah melintang pengerolan akan tegak lurus terhadap bidang slip sehingga dislokasi akan sangat sulit bergerak. Pergerakan dislokasi ini berpengaruh terhadap kekuatan material. Dislokasi yang semakin mudah bergerak pada bidang slip maka kekuatannya semakin rendah, sebaliknya apabila dislokasi semakin sulit bergerak pada bidang slip maka kekuatan material semakin tinggi $[13,14,15]$. Dengan demikian, sampel searah dengan pengerolan (sampel C) kekuatannya lebih rendah dan regangannya lebih besar dibandingkan sampel $A$ dan $B$. Keempat sampel $A, B, C$, dan $D$ mempunyai regangan cukup besar. Hal ini menunjukkan paduan AlMg2 pasca pengerolan merupakan material ulet yang ditandai dengan adanya fenomena necking sebelum patah pada proses pengujian tariknya. Fenomena ini diperkuat dengan struktur mikro di daerah patahannya yang diperlihatkan pada Gambar 2. 


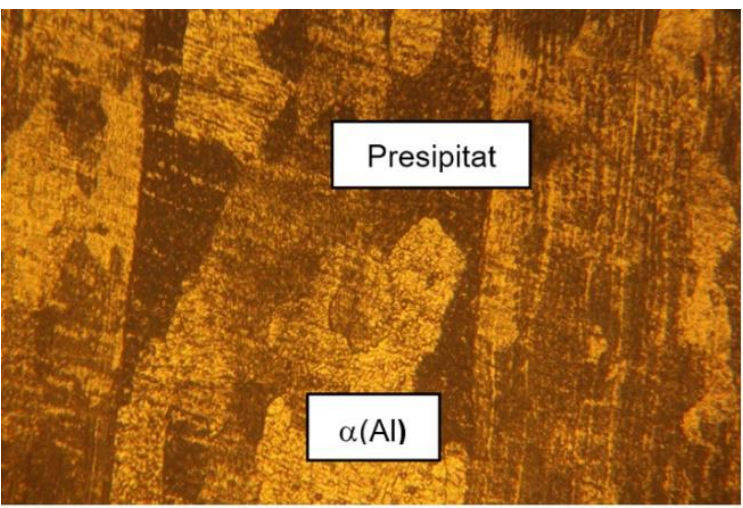

$\underline{200 \mu \mathrm{m}}$

(a)

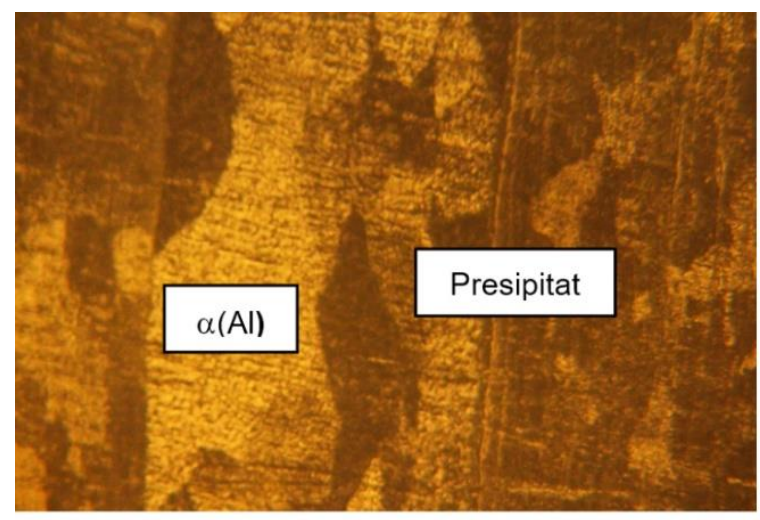

$\underline{200 \mu \mathrm{m}}$

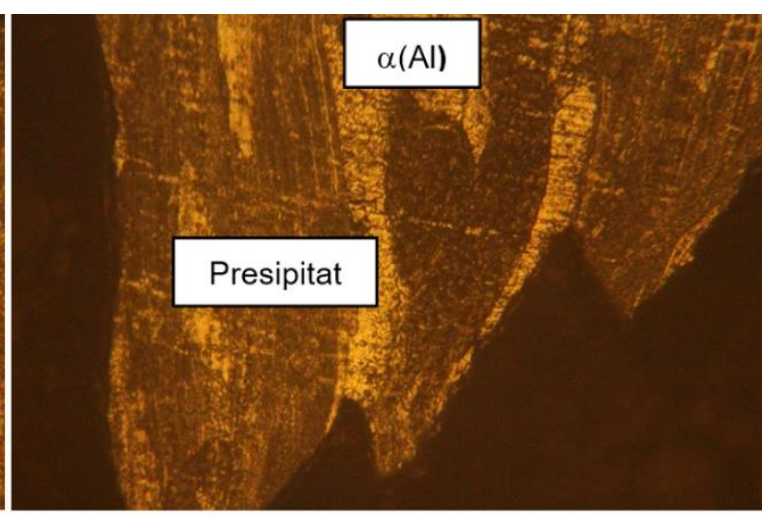

$\underline{200 \mu \mathrm{m}}$

(b)

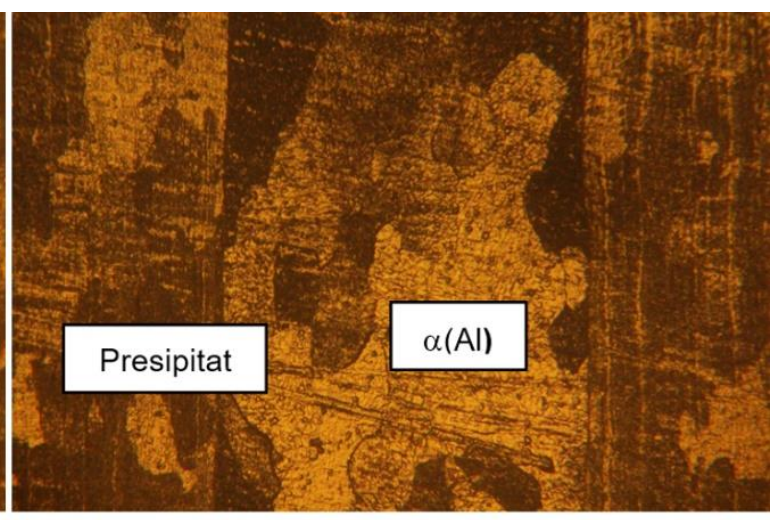

$\underline{200 \mu \mathrm{m}}$

(d)

(c)

Gambar 2. Mikrograf sampel AlMg2 pasca uji tarik.

a) Daerah base metal untuk ketebalan sampel $1,40 \mathrm{~mm}$

b) Daerah patahan unuk ketebalan sampel $1,40 \mathrm{~mm}$

c) Daerah base metal untuk ketebalan sampel $3,15 \mathrm{~mm}$

d) Daerah patahan untuk ketebalan sampel 3,15 mm

Gambar 2(a) dan (c) memperlihatkan struktur mikro base metal paduan AlMg2 masing-masing dengan ketebalan 1,40 dan 3,15 mm. Struktur kedua base metal adalah sama yaitu fasa $\alpha(\mathrm{Al})$ (berwarna terang) dan sejumlah besar senyawa fasa kedua (presipitat) yang terdistribusi di sepanjang butir-butir batang (berwarna gelap) searah dengan pengerolan sampel. Menurut Bo Wang, presipitat tersebut adalah $\mathrm{Mg}_{2} \mathrm{Si}$, $\mathrm{Al}_{3} \mathrm{Fe}$, dan $\mathrm{Mg}_{2} \mathrm{Al}_{3}[7]$. Struktur mikro pada daerah patahan sampel tarik AIMg2 ketebalan 1,40 mm (Gambar 2 b) mempunyai struktur butir pipih memanjang searah dengan penarikan [13,14]. Struktur butir pipih ini lebih panjang dan lebar dibandingkan struktur butir pipih di daerah patahan dari sampel AlMg2 dengan ketebalan 3,15 mm. Butir yang lebih pipih memiliki rasio luas permukaan yang lebih besar terhadap volume, yang berarti rasio batas butir dengan dislokasi yang lebih besar. Semakin banyak batas butir yang ada, semakin tinggi kekuatannya. Pada butiran lebih pipih, semakin sulit dislokasi yang dapat menempuh jarak lebih dari 1 (satu) unit. Jenis penguatan ini dikenal sebagai penguatan Hall-Petch, yang dinyatakan dengan persamaan, $\sigma_{y}=\sigma_{i}+k_{y} \cdot d^{-1 / 2}$ dengan $\sigma_{y}$ adalah kekuatan luluh, $\sigma_{i}$ adalah kekuatan internal, $\mathrm{k}_{\mathrm{y}}$ 
adalah konstanta tegangan dan d adalah ukuran butir [1]. Dengan demikian, kekuatan luluh dan regangan paduan AIMg2 dengan ketebalan 1,40 mm lebih besar dibandingkan ketebalan $3,15 \mathrm{~mm}$.

Gambar 3 menunjukkkan kekerasan base metal dan daerah patahan tarik sampel paduan AlMg2. Dari Gambar 3 diketahui bahwa untuk sampel tarik ketebalan 1,4 mm, kekerasan bagian patahan $(46,2 \mathrm{VHN})$ lebih tinggi dibandingkan kekerasan dekat patahan $(40,1 \mathrm{VHN})$ dan base metal, (38,6 VHN). Demikian pula untuk sampel tarik ketebalan $3,15 \mathrm{~mm}$, kekerasan bagian patahan $(45,6$ VHN) lebih tinggi dibandingkan kekerasan dekat patahan $(43,5 \mathrm{VHN})$ dan base metal $(42,1 \mathrm{VHN})$. Kekerasan dekat patahan kedua sampel tarik lebih tinggi dibandingkan base metalnya. Kekerasan di daerah patahan sampel tarik paduan AIMg2 relatif sama pada ketebalan $1,4 \mathrm{~mm}$ dan $3,15 \mathrm{~mm}$. Hal ini menunjukkan bahwa ketebalan pelat AIMg2 tidak berpengaruh terhadap kekerasan di daerah patahan. Kekerasan di daerah patahan disebabkan adanya fenomena pengerasan regangan (strain hardening) yang menyebabkan kekuatannya lebih tinggi. Hal ini sesuai dengan persamaan empiris untuk material ulet: VHN $\leq$ (UTS/3), dengan VHN adalah nilai kekerasan Vickers dan UTS adalah kekuatan tarik rekayasa (MPa) [16].

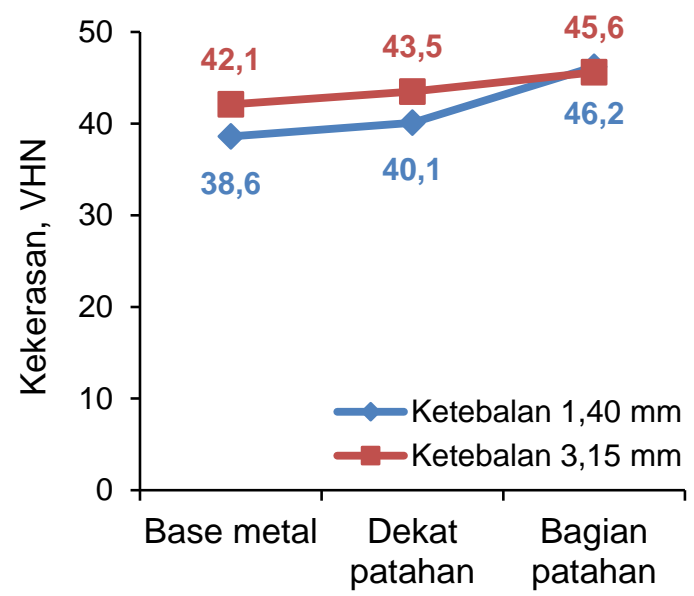

Gambar 3. Kekerasan daerah patahan tarik sampel paduan AIMg2

\section{Spesimen Mini}

Spesimen mini merupakan salah satu solusi untuk meminimalkan limbah radioaktif dalam pengujian mekanik pelat elemen bakar nuklir. Permasalahan timbul di daerah bekas pemotongan spesimen yang dibuat dengan mesin punching. Gambar 4 menunjukkan mikrograf spesimen mini paduan AA 5052 ketebalan 1,35 mm. Pada Gambar 4 terlihat adanya daerah deformasi pada bagian kiri (Gambar 4a) dan bagian kanan spesimen searah pengerolan (Gambar 4b), bagian kiri (Gambar 4c) dan bagian kanan spesimen arah melintang pengerolan (Gambar 4d). Daerah deformasi pada spesimen disebabkan adanya gaya geser pada proses pemotongan (shear cutting) spesimen mini menggunakan mesin punching[6]. Selanjutnya, masing-masing daerah deformasi pada spesimen mini diukur lebarnya dan hasilnya ditunjukkan dalam Tabel 4. Dari Tabel 4 diketahui lebar rerata daerah deformasi untuk spesimen searah pengerolan, yaitu sisi kiri dalam rentang 0,22 $-0,546 \mathrm{~mm}$ dan sisi kanan 0,233-0,404 mm. Lebar rerata daerah deformasi spesimen arah melintang pengerolan untuk sisi kiri dalam rentang $0,269-0,400 \mathrm{~mm}$ dan sisi kanan 0,296-0,317 $\mathrm{mm}$. Oleh karena lebar daerah deformasi relatif sama, maka lebar daerah deformasi tidak dipengaruhi arah pengerolan, tetapi hanya dipengaruhi oleh ketebalan dan ketajaman pisau pemotong mesin punching. Semakin tipis dan tajam pisau pemotong, akan dihasilkan daerah deformasi semakin sempit atau sebaliknya.

Daerah deformasi pada spesimen dapat dihilangkan dengan cara mekanik yaitu dipotong menggunakan diamond cutting yang sangat tipis dengan kecepatan lambat atau menggunakan mesin grinding dengan kecepatan putar rendah untuk meminimalkan terjadinya daerah deformasi. Selanjutnya, kekerasan spesimen mini pasca pemotongan daerah deformasi dibandingkan dengan kekerasan pada daerah deformasi, seperti ditunjukkan dalam Tabel 5 . 


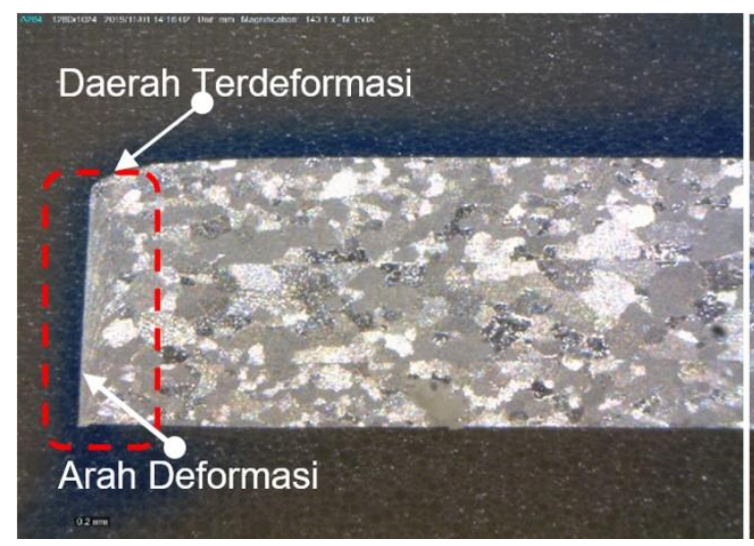

(a)

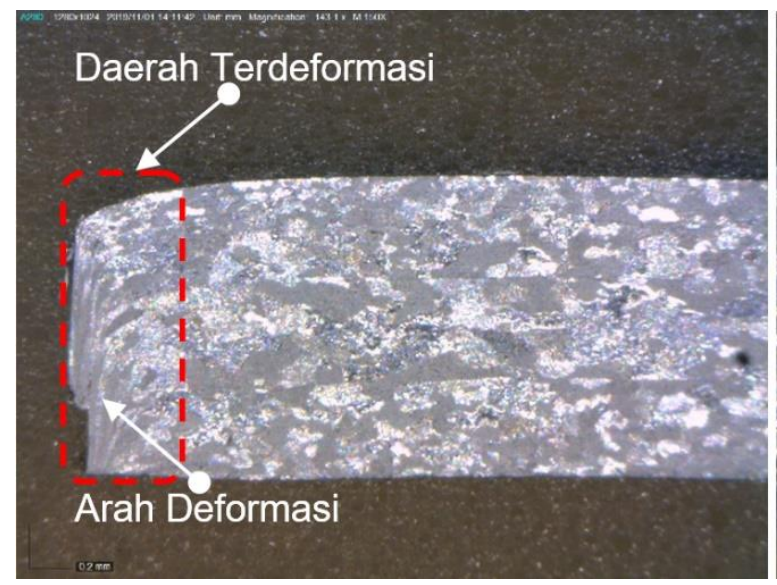

(c)

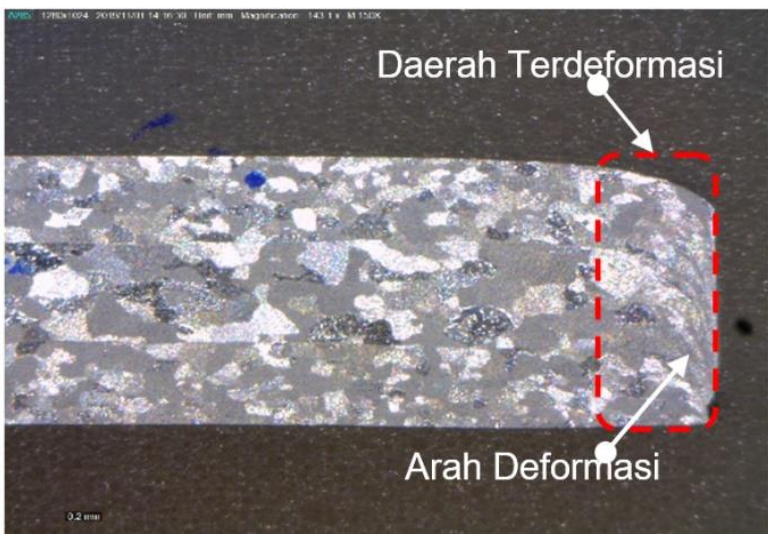

(b)

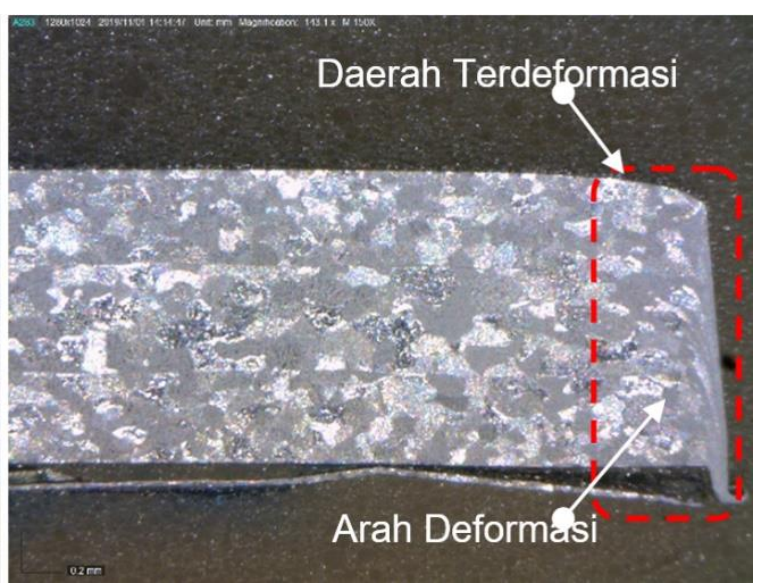

(d)

Gambar 4. Mikrograf spesimen mini paduan AA 5052 ketebalan 1,35 mm.

a. Daerah dekat potongan bagian kiri spesimen searah pengerolan.

b. Daerah dekat potongan bagian kanan spesimen searah pengerolan.

c. Daerah dekat potongan bagian kiri spesimen arah melintang pengerolan.

d. Daerah dekat potongan bagian kanan spesimen arah melintang pengerolan.

Tabel 4. Daerah deformasi sampel mini akibat shear cutting.

\begin{tabular}{lccc}
\hline & & Daerah deformasi & Lebar rerata, $\mathrm{mm}$ \\
\hline \multirow{4}{*}{ Searah pengerolan } & \multirow{2}{*}{ Sampel-1 } & Sisi kiri & 0,220 \\
& & Sisi kanan & 0,266 \\
& \multirow{2}{*}{ Sampel-2 } & Sisi kiri & 0,247 \\
& & Sisi kanan & 0,233 \\
& \multirow{2}{*}{ Sampel-3 } & Sisi kiri & 0,546 \\
& \multirow{2}{*}{ Arah melintang pengerolan } & Sisi kanan & 0,404 \\
\hline \multirow{2}{*}{ Sampel-1 } & Sampel-2 & Sisi kiri & 0,313 \\
& & Sisi kiri & 0,317 \\
& \multirow{3}{*}{ Sampel-3 } & Sisi kanan & 0,400 \\
& & Sisi kiri & 0,296 \\
& & Sisi kanan & 0,269 \\
& & & 0,299 \\
\hline
\end{tabular}


Tabel 5. Kekerasan spesimen mini paduan AIMg2.

\begin{tabular}{lccc}
\hline \multirow{2}{*}{ Sampel } & & \multicolumn{2}{c}{ Kekerasan rerata, VHN } \\
\cline { 3 - 4 } & & Daerah deformasi & $\begin{array}{c}\text { Pasca pemotongan } \\
\text { daerah deformasi }\end{array}$ \\
\hline \multirow{2}{*}{ Searah pengerolan } & Sisi kiri & 66,9 & 53,6 \\
\multirow{2}{*}{ Arah melintang pengerolan } & Sisi kanan & 66,9 & \multirow{2}{*}{53,0} \\
& Sisi kiri & 73,6 & 65,0 \\
\hline
\end{tabular}

Pada Tabel 5 terlihat kekerasan daerah deformasi spesimen mini searah pengerolan adalah 66,9 VHN relatif sama dengan arah melintang pengerolan, yaitu $65,0-73,6$ VHN. Hal ini menunjukkan bahwa kekerasan di daerah deformasi tidak dipengaruhi oleh arah pengerolan, tetapi gaya geser pada saat pembuatan spesimen mini [6,11]. Kekerasan rerata spesimen searah pengerolan tanpa daerah deformasi adalah 53,6 VHN relatif sama dengan spesimen arah melintang pengerolan yaitu 53,0 VHN. Hal ini berarti bahwa efek shear cutting dapat ditiadakan dengan cara perlakuan mekanik, yaitu pemotongan atau pengampelasan pada permukaan bekas potong sampel mini cladding bahan bakar reaktor riset.

\section{SIMPULAN}

Perilaku tarik paduan AIMg2 dipengaruhi oleh gauge length, ketebalan dan arah pengerolan sampel uji. Sampel arah melintang pengerolan dengan gauge length lebih besar mempunyai kekuatan tarik, kekuatan luluh, kekuatan patah dan regangan lebih tinggi dibandingkan dengan gauge length lebih kecil. Sampel arah melintang pengerolan dengan gauge length lebih kecil dan ketebalan lebih besar mempunyai kekuatan tarik, kekuatan luluh, kekuatan patah dan regangan lebih tinggi dibandingkan dengan gauge length lebih besar dan ketebalan lebih kecil. Sampel searah pengerolan lebih ulet dibandingkan sampel arah melintang pengerolan. Paduan AlMg2 pasca pengerolan panas merupakan material ulet dengan struktur terdiri atas fasa
$\alpha(\mathrm{Al})$ dan presipitat yang terdistribusi di sepanjang butir batang pipih searah dengan pengerolan sampel.

Lebar rerata daerah deformasi searah pengerolan yaitu $0,22-0,546 \mathrm{~mm}$, sedangkan arah melintang pengerolan adalah 0,269-0,400 $\mathrm{mm}$. Kekerasan daerah deformasi searah pengerolan adalah 66,9 $\mathrm{VHN}$ dan arah melintang pengerolan adalah 65,0 - 73,6 VHN. Gaya geser pada pembuatan spesimen mini berpengaruh terhadap lebar dan kekerasan daerah deformasi. Efek shear cutting dapat ditiadakan dengan pemotongan atau pengampelasan pada permukaan bekas potong spesimen mini cladding bahan bakar reaktor riset.

\section{UCAPAN TERIMA KASIH}

Penulis mengucapkan terima kasih kepada Juan Carlos Sihotang, Guswardani dan Purwanta yang telah membantu pelaksanaan penelitian ini.

\section{DAFTAR PUSTAKA}

[1] C. R. F. Azevedo, "Selection of fuel cladding material for nuclear fission reactors," Engineering Failure Analysis. pp. 1943-1962, 2011.

[2] W. R. Marcum, D. M. Wachs, A. B. Robinson, and M. A. Lillo, "Aluminum cladding oxidation of prefilmed in-pile fueled experiments," J. Nucl. Mater., vol. 471, pp. 136-148, 2016.

[3] A. Bhowmik and D. Mishra, "A Comprehensive Study of an Aluminum Alloy AL-5052," Adv. Phys. Lett., vol. 3, 2018. 
[4] D. Gong, S. Huang, G. Wang, and K. Wang, "Heat Transfer Calculation on Plate-Type Fuel Assembly of High Flux Research Reactor," Sci. Technol. Nucl. Install., vol. 2015, no. Article ID 198654, 2015.

[5] K. Yanagisawa, T. Fujishiro, O. Horiki, K. Soyama, H. Ichikawa, and T. Kodaira, "Transient behavior of low enriched uranium silicide plate-type fuel for research reactors during reactivity initiated accident conditions," J. Nucl. Sci. Technol., vol. 30, no. 8, pp. 741-751, 1993.

[6] Sungkono, M. K. Ajiriyanto, and S. Ismarwanti, "Microstructural characterization and mechanical properties of mini specimen of research reactor fuel cladding," Indian J. Eng. Mater. Sci., vol. 27, pp. 490 495, 2020.

[7] W. Bo, X. Chen, F. Pan, J. Mao, and F. Yong, "Effects of cold rolling and heat treatment on microstructure and mechanical properties of AA 5052 aluminum alloy," Trans. Nonferrous Met. Soc. China, vol. 25, no. 8, pp. 2481-2489, 2015.

[8] D. Singh, P. N. Rao, and R. Jayaganthan, "Effect of deformation temperature on mechanical properties of ultrafine grained $\mathrm{Al}-\mathrm{Mg}$ alloys processed by rolling," Mater. Des., vol. 50, pp. 646-655, 2013.

[9] R. Procházka, J. Džugan, and $M$. Kövér, "Miniature specimen tensile testing of AZ31 alloy processed by ECAP," Arch. Mater. Sci. Eng., vol. 76, no. 2, pp. 134-139, 2015.
[10] E. M. Rabenberg, "Small Specimen Test Techniques for Evaluating Radiation-Induced Changes in Mechanical Properties," 2012.

[11] ASTM B209M-14, Standard Specification for Aluminum and Aluminum-Alloy Sheet and Plate. ASTM International.

[12] V. Mugendiran, A. Gnanavelbabu, and R. Ramadoss, "Tensile behaviour of Al5052 alloy sheets annealed at different temperatures," in Advanced Materials Research, 2014, vol. 845, pp. 431-435.

[13] X. Xiaojing, J. Ling, L. Wenjun, L. Yudong, F. Zhendan, and C. Cheng, "Effect of Rolling and Subsequent Heat Treatment on Tensile Property and Crystal Orientation of 5052 Al Alloy," Rare Met. Mater. Eng., vol. 43, no. 1, pp. 245-248, 2014.

[14] O. V Mishin, A. Godfrey, D. J. Jensen, and N. Hansen, "Recovery and recrystallization in commercial purity aluminum cold rolled to an ultrahigh strain," Acta Mater., vol. 61, no. 14, pp. 5354-5364, 2013.

[15] S. L. Xia, M. Ma, J. X. Zhang, W. X. Wang, and W. C. Liu, "Effect of heating rate on the microstructure, texture and tensile properties of continuous cast AA 5083 aluminum alloy," Mater. Sci. Eng. A, vol. 609, pp. 168-176, 2014.

[16] P. Zhang, S. X. Li, and Z. F. Zhang, "General relationship between strength and hardness," Mater. Sci. Eng. A, vol. 529, pp. 62-73, 2011. 
